\title{
Analisis Pemberian Medication Aids terhadap Ketaatan Pasien Diabetes Melitus Tipe 2 di Beberapa Puskesmas Kota Pekanbaru
}

\author{
Analysis of Improvement in Medication Adherence by Using Medication Aids \\ in Type 2 Diabetic Mellitus Outpatients \\ in Community Health Centers Pekanbaru City
}

\author{
Fina Aryani ${ }^{*}$, Welny Noverianti, Septi Muharni \\ Sekolah Tinggi Ilmu Farmasi Riau, \\ JI Kamboja Simpang Baru Tampan, Pekanbaru, Riau, 28289, Indonesia \\ *Corresponding author email: finaaryani@stifar-riau.ac.id
}

Available online 30-12-2019

\begin{abstract}
ABSTRAK
Diabetes Mellitus (DM) merupakan penyakit metabolik kronik dimana pasien DM tidak bisa memproduksi insulin dalam jumlah yang cukup atau tidak mampu menggunakan insulin secara efektif sehingga terjadi kelebihan glukosa darah. DM merupakan penyakit degeneratif yang memerlukan pengobatan jangka panjang sehingga dituntut ketaatan pasien dalam menggunakan obat. Salah satu upaya untuk meningkatkan ketaatan adalah dengan pemberian Medication Aids. Tujuan penelitian ini untuk mengetahui pengaruh pemberian Medication Aids terhadap ketaatan pasien DM tipe 2 di beberapa Puskesmas Kota Pekanbaru. Penelitian ini menggunakan metode eksperimen semu (quasi experiment), dengan rancangan Non Randomized Control Group Pretest and Posttest Design yang dilakukan terhadap 100 pasien yang dikelompokkan menjadi 50 pasien kelompok kontrol dan 50 pasien kelompok perlakuan. Metode pengambilan sampel secara purposive sampling. Pengumpulan data ketaatan pasien menggunakan MMAS-8. Data dianalisis menggunakan uji statistik Mann-Whitney. Hasil penelitian menunjukkan nilai $p=0,000(p<0,005)$ yang artinya terdapat pengaruh pemberian wadah pengingat pil dan kemasan sekali pakai terhadap tingkat ketaatan pasien DM tipe 2 .
\end{abstract}

Kata kunci: diabetes mellitus, ketaatan, medication aids.

\section{ABSTRACT}

Diabetes Mellitus (DM) is a chronic metabolic disease characterized by limited production of insulin or ineffective insulin utilization that resulting in the rise of blood glucose levels. As a degenerative disease, DM requires long-term medication that demanding patient adherence in drugs uses.One of the efforts to increase patient 
adherence is the Medication Aids program. The aim of this study is to determine the effect of pill reminder and disposable packaging on the level of adherence of DM type 2 outpatients in some Community Health Centers in Pekanbaru. This study used a quasiexperimental method with a non-randomized control group pretest and posttest design involving 100 patients equally divided into controlled and treatment groups. Purposive sampling method was used for data collection. Patient adherence data were collected by following MMAS-8. The obtained data were analyzed using the Mann-Whitney statistical test. The results of the experiment showed $p=0.000(p<0.005)$, indicated that the use of pill reminder and disposable packaging affected the level of adherence of DM patients.

Key words: adherence, diabetes mellitus, medication aids.

\section{Pendahuluan}

Diabetes Melitus

(DM)

merupakan penyakit metabolik yang berlangsung kronik di mana penderita diabetes tidak bisa memproduksi insulin dalam jumlah yang cukup atau tidak mampu menggunakan insulin secara efektif sehingga terjadi kelebihan gula dalam darah dan baru dirasakan setelah terjadi komplikasi lanjut pada organ tubuh (Misnadiarly, 2006). Menurut American Diabetes Association (ADA) tahun 2003, DM merupakan suatu kelompok penyakit metabolik dengan karakteristik hiperglikemia yang terjadi karena kelainan sekresi insulin, kerja insulin, atau kedua-duanya (American Diabetes Association, 2003).

Menurut World Health
Organization (WHO) angka kejadian kasus DM di Indonesia saat ini terus meningkat hingga mencapai 8,4 juta jiwa dan diprediksi jumlahnya akan melebihi 21 juta jiwa pada tahun 2025 mendatang serta lebih banyak terjadi pada rentang usia muda atau masa produktif. Di Riau prevalensi DM menduduki peringkat ketiga setelah Kalimantan dan Maluku, yaitu 10,4\% (WHO, 2008). Sementara penderita DM untuk wilayah Pekanbaru pada Triwulan I tahun 2012 terdapat 2.897 jiwa (Dinkes Kota Pekanbaru, 2013).

Menurut WHO ketaatan ratarata pasien pada terapi terhadap penyakit di negara maju hanya sebesar $50 \%$ sedangkan di negara berkembang, jumlah tersebut bahkan lebih rendah (WHO, 2003). Sedangkan berdasarkan penelitian Alfian et al. (2016) menyatakan bahwa tingkat ketaatan pasien terhadap pengobatan diabetes yang diukur dengan MMAS, menunjukkan bahwa $49,4 \%$ pasien memiliki ketaatan rendah, $29,7 \%$ pasien memiliki ketaatan sedang, dan 20,9\% pasien memiliki ketaatan tinggi. Penelitian sebelumnya menunjukkan bahwa pasien tidak taat terhadap pengobatan yang diberikan dokter di sebabkan kerena kelupaan sebesar $30 \%$ dan kurang informasi tentang penggunaan obat yang diberikan sekitar 9\% (Osterberg dan Blaschke, 2005).

Ketaatan didefinisikan sebagai seberapa jauh prilaku seseorang (dalam hal menggunakan obat, mengikuti diet, atau mengubah gaya hidup) sesuai 
dengan nasehat medis atau saran kesehatan, sehingga tidak terjadi hal yang membahayakan hasil terapi pasien. Ketaatan pasien dalam melakukan pengobatan merupakan salah satu faktor penentu dalam keberhasilan pengobatan. Ketidaktaatan akan menyebabkan menurunnya keberhasilan terapi. Selain itu, ketidaktaatan dapat memperpanjang masa sakit atau meningkatkan keparahan penyakit dan sejumlah akibat yang tidak diinginkan, seperti sakit bertambah lama atau kondisi medis memburuk sehingga pasien perlu perawatan di rumah sakit atau akibat ekstrem, yaitu kematian (Rantucci, 2009).

Tingginya angka kejadian pasien yang lupa minum obat menunjukkan bahwa perlunya suatu alat bantu yang dapat meningkatkan ketaatan pasien dalam meminum obat. Alat bantu pengingat pasien minum obat merupakan alat bantu konseling farmasis yang diberikan ke pasien untuk memantau dan meningkatkan ketaatan penggunaan obat khususnya untuk penyakit kronis. Salah satu contoh alat bantu pengingat obat tersebut adalah wadah pengingat pil dan kemasan sekali pakai. Wadah pengingat pil yang digunakan tersedia dalam berbagai ukuran untuk jadwal harian atau mingguan yang dapat membantu pasien dengan mengarahkan pasien untuk tetap mengikuti jalur waktu penggunaan obat setelah penggunaan obat sebelumnya. Sedangkan kemasan sekali pakai dapat membantu memberikan satu dosis pengobatan pada waktu yang sama
(Rantucci, 2009). Selain itu, bentuk yang portable dari wadah pengingat pil dan kemasan sekali pakai dapat memudahkan pasien dalam membawa obat sehingga dapat meningkatkan ketaatan pasien.

Berdasarkan penelitian Winasthi (2010), tentang pengaruh pemberian alat bantu ketaatan dan informasi saat home visit pada perilaku pasien ISPA Puskesmas Kalibawang dengan menggunakan alat bantu ketaatan, yaitu wadah pengingat pil, menyimpulkan bahwa pada pasien ISPA rawat jalan Puskesmas Kalibawang periode Juni-Juli 2010 yang mendapatkan alat bantu ketaatan dan informasi obat memiliki dampak terapi yang lebih baik dibandingkan dengan ketaatan pasien ISPA yang tidak mendapatkan alat bantu ketaatan dan informasi obat pada baseline yang sama. Hasil ini dibuktikan berdasarkan uji Z-test didapatkan zhit sebesar $-1,845$ yang berada di critical area.

Penelitian di Kota Pekanbaru sendiri belum dilakukan tentang pengaruh pemberian wadah pengingat pil terhadap dampak terapi pasien. Berdasarkan pemilihan sampel puskesmas secara acak, maka dari 20 puskesmas yang terdapat di Kota Pekanbaru dipilih 4 puskesmas yang terletak di 4 kecamatan yang berbeda di kota Pekanbaru untuk dijadikan populasi penelitian di antaranya Puskesmas Simpang Tiga, Kecamatan Marpoyan Damai, Puskesmas Harapan Raya, Kecamatan Bukit Raya, Puskesmas Senapelan, Kecamatan Senapelan, dan 
Puskesmas Rumbai, Kecamatan Rumbai Pesisir.

Berdasarkan data profil kesehatan Kota Pekanbaru tahun 2014, diketahui 4 Kecamatan tersebut yaitu Kecamatan Marpoyan Damai, Kecamatan Bukit Raya, Kecamatan Senapelan, dan Kecamatan Rumbai Pesisir memiliki jumlah penduduk yang cukup banyak yaitu berkisar 140.904, 149.889, 40.139, dan 75.457 jiwa sehingga cukup memberi pengaruh terhadap peningkatan derajat kesehatan bila diberi suatu intervensi. Selain itu, berdasarkan hasil survei peneliti di Puskesmas Simpang Tiga terdapat 10.245 kunjungan selama tahun 2016, sedangkan di Puskesmas Rumbai Pesisir terdapat 258 kunjungan selama 7 bulan terakhir pada tahun 2016. Selain itu, DM termasuk 10 penyakit terbesar di kedua puskesmas tersebut. Selama ini belum pernah dilakukan penelitian tentang pengaruh pemberian wadah pengingat pil dan kemasan sekali pakai terhadap ketaatan dalam pengobatan DM di 4 puskesmas tersebut. Berdasarkan hal tersebut maka perlu dilakukan penelitian mengenai analisis pemberian wadah pengingat pil dan kemasan sekali pakai terhadap ketaatan pasien diabetes melitus tipe 2 di beberapa Puskesmas Kota Pekanbaru.

\section{Metode Penelitian}

Penelitian ini menggunakan metode eksperimen semu (quasi experiment), dengan rancangan Non Randomized Control Group Pretest dan Posttest Design yang dilakukan selama bulan Oktober 2016-Januari 2017 di beberapa Puskesmas Kota Pekanbaru yaitu Puskesmas Simpang Tiga, Puskesmas Harapan Raya, Puskesmas Senapelan, dan Puskesmas Rumbai. Metode pengambilan sampel secara purposive sampling yang terdiri dari 100 pasien yang dikelompokkan menjadi 50 pasien kelompok kontrol dan 50 pasien kelompok perlakuan. Sampel pada penelitian ini adalah pasien diabetes melitus tipe 2 di empat puskesmas yang memenuhi kriteria inklusi yakni pasien dengan usia $\geq 25$ tahun, pasien yang dapat membaca dan menulis, pasien DM yang menggunakan antidiabetik oral, pasien yang bersedia menjadi responden, pasien yang dapat dihubungi kembali, dan pasien yang menggunakan obat DM pada periode sebelumnya. Sumber data pada penelitian ini adalah data primer dan sekunder. Data primer merupakan data hasil pengumpulan data yang diperoleh dari wawancara langsung dengan pasien diabetes melitus. Sedangkan data sekunder didapatkan dari data pasien diabetes melitus yang diperoleh dari puskesmas. Sedangkan alat yang digunakan adalah lembar wawancara, wadah pengingat pil dan kemasan sekali pakai. Pengumpulan data ketaatan pasien menggunakan MMAS-8 dan dianalisis menggunakan uji statistik Mann-Whitney.

\section{Hasil dan Pembahasan}

Dalam penelitian ini, digunakan sampel sebanyak 100 pasien DM tipe 2 yang berobat ke 4 Puskesmas Kota Pekanbaru (Puskesmas Simpang Tiga, 
Puskesmas Harapan Raya, Puskesmas

Analisis Berdasarkan Data

Senapelan, Puskesmas Rumbai) yang Sosiodemografi Pasien

Sebagian besar pasien berjenis Pasien tersebut dibagi menjadi 2 kelamin perempuan (59\%) (Gambar 1). kelompok yaitu 50 pasien sebagai Penelitian sejalan yang dilakukan oleh kelompok kontrol dan 50 pasien lainnya sebagai kelompok perlakuan. Kemudian data dianalisis secara univariat dan bivariat.

Analisis univariat yang dilakukan dalam penelitian ini yaitu untuk melihat distribusi pasien berdasarkan data sosiodemografi, pola penyakit pasien, pola hidup pasien, serta melihat tingkat ketaatan baik kelompok kontrol maupun perlakuan dari pasien DM tipe 2 tersebut. Data sosiodemografi pasien yang diteliti pada penelitian ini adalah rentang usia, jenis kelamin, dan pendidikan.

Wijaya et al. (2015), di puskesmas wilayah kerja Surabaya Timur bahwa prevalensi DM lebih banyak terjadi pada jenis kelamin perempuan yaitu 94 orang (68,12\%) dibandingkan dengan jenis kelamin laki-laki yang hanya berjumlah 44 orang $(31,88 \%)$ saja. Penelitian ini juga sejalan dengan yang dilakukan oleh Trisnawati dan Setyorogo (2013) di Puskesmas Kecamatan Cengkareng, Jakarta Barat bahwa prevalensi DM banyak terjadi pada jenis kelamin perempuan yaitu 18 orang $(58,16 \%)$ dibandingkan jenis kelamin laki-laki yang hanya berjumlah 13 orang $(41,84 \%)$ saja.

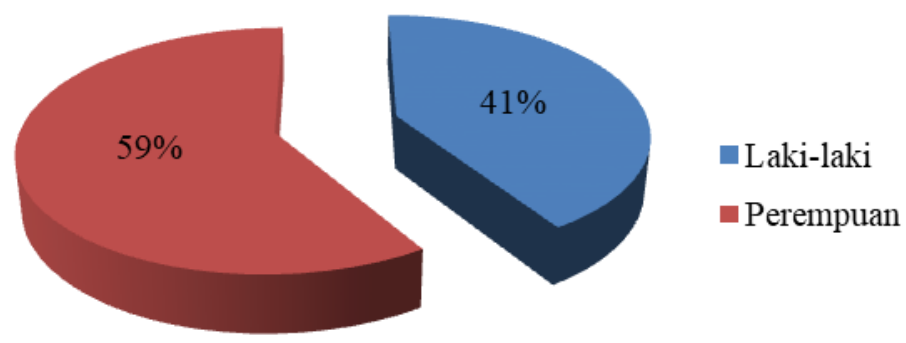

Gambar 1. Diagram hasil analisis data berdasarkan jenis kelamin.

\section{Berdasarkan data Badan Pusat} Statistik Kota Pekanbaru mengenai kependudukan di 4 kecamatan yang diteliti, diketahui kependudukan perempuan lebih banyak dibandingkan dengan laki-laki sehingga angka kejadian penyakit juga lebih banyak pada perempuan dibandingkan laki-laki. Tingginya persentase pasien perempuan dibandingkan laki-laki dapat disebabkan oleh berbagai faktor seperti obesitas, penggunaan kontrasepsi oral, faktor 
hormonal, stress, dan riwayat DM menemukan bahwa kelompok umur gestasional (Therney et al., 2002).

Berdasarkan hasil penelitian yang paling banyak menderita DM adalah kelompok umur 45-52 (47,5\%). yang dilakukan, didapatkan hasil rentang usia 45-64 tahun paling banyak Peningkatan resiko diabetes seiring dengan umur, khususnya pada usia lebih menderita penyakit DM tipe 2 yaitu sebesar 65\% (Gambar 2). Hasil ini sejalan dengan penelitian Iswanto (2004) yang juga menemukan bahwa ada hubungan yang signifikan antara umur dengan kejadian diabetes melitus. Studi lain dari 40 tahun, disebabkan karena pada usia tersebut mulai terjadi peningkatan intoleransi glukosa. Adanya proses penuaan menyebabkan berkurangnya kemampuan sel $\beta$ pankreas dalam yang dilakukan Sunjaya (2009) juga memproduksi insulin (Sunjaya, 2009).

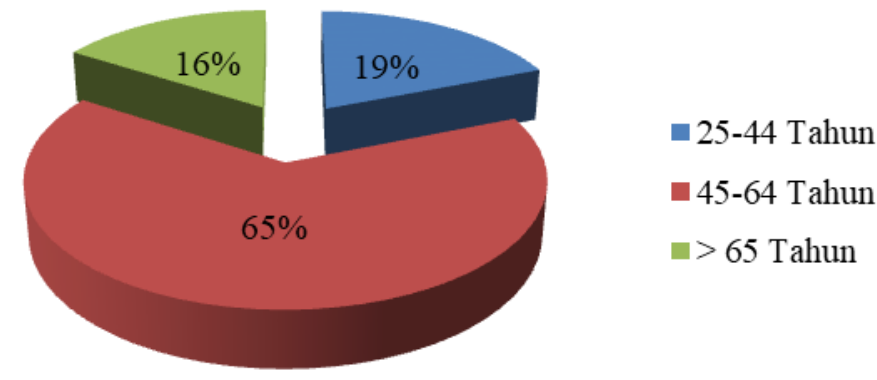

Gambar 2. Diagram hasil analisis data berdasarkan jenis usia.

Sedangkan analisis berdasarkan pendidikan terakhir menunjukkan bahwa pasien yang menderita penyakit DM tipe 2 paling banyak yaitu dengan tingkat pendidikan menengah sebanyak $62 \%$. Menurut Ayu dan Damayanti (2015) menyimpulkan bahwa pendidikan memiliki andil yang kuat dalam peningkatan pengetahuan seseorang untuk melakukan sesuatu yang penting bagi kesehatannnya. Hal ini juga ditemui pada Mrcos (2005) bahwa DM tipe 2 dapat saja diderita pada semua lapisan pendidikan, namun kepatuhan berobat ternyata lebih berhasil pada pasien dengan pendidikan yang cukup tinggi dari pada yang berpendidikan rendah.

Banyaknya pasien yang menderita DM dengan tingkat pendidikan menengah dapat disebabkan karena berdasarkan data dari Badan Pusat Statistik Kota Pekanbaru diketahui bahwa tingkat pendidikan di kota Pekanbaru dengan tingkat pendidikan rendah sebanyak 261.247 jiwa (32\%), tingkat pendidikan menengah sebanyak 448.212 jiwa $(55,93 \%)$ dan tingkat pendidikan tinggi sebanyak 91.918 jiwa 
(11,47\%). Sehingga terlihat bahwa masyarakat untuk memanfaatkan subsidi tingkat pendidikan menengahlah yang yang diberikan oleh pemerintah secara paling banyak di wilayah Kota Pekanbaru gratis dalam bentuk program Jaminan yaitu 55,93\% (BPS, 2010). Selain itu, Kesehatan Nasional (JKN) (Napirah et al., kondisi sosial ekonomi masyarakat yang 2016).

tidak terlalu tinggi mendorong

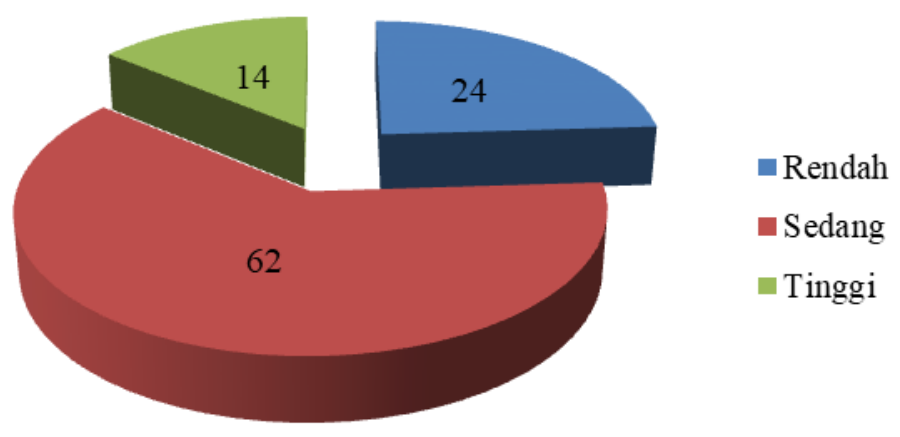

Gambar 3. Diagram hasil analisis data berdasarkan pendidikan terakhir.

\section{Analisis Berdasarkan Data Penyakit} Pasien

Berdasarkan hasil penelitian didapat persentase lama menderita $\geq 2$ tahun sebanyak $98 \%$ yang terdiri dari lama menderita 10 tahun sebanyak $2 \%$, lama menderita 8 tahun sebanyak $6 \%$, lama menderita 4 tahun sebanyak $21 \%$, dan lama menderita 3 tahun sebanyak $69 \%$. Faktor utama pencetus komplikasi pada diabetes melitus adalah durasi dan tingkat keparahan diabetes (Depkes RI, 2005). Berdasarkan penelitian Bernal et al. (2000) menemukan bahwa pasien yang telah lama menderita DM namun disertai komplikasi memiliki efikasi diri yang rendah. Dengan adanya komplikasi akan mempengaruhi kemampuan pasien untuk mengelola perawatan diri dan penyakitnya. Semakin lama pasien menderita diabetes, semakin kecil kemungkinan untuk menjadi patuh terhadap pengobatan. Sebaliknya, menurut Abrahim (2011) menyatakan bahwa lama sakit pasien DM tipe 2 memiliki korelasi positif, dimana pasien yang telah lama menderita DM tipe 2 memiliki pengalaman serta telah belajar dari rasa sakit yang telah ia alami sehingga kepatuhan pasien meningkat seiring berjalannya waktu. 
Tabel 1. Hasil analisis data penyakit pasien

\begin{tabular}{|c|c|c|c|}
\hline \multirow{2}{*}{ No } & \multirow{2}{*}{ Data Penyakit dan Gaya Hidup } & \multicolumn{2}{|c|}{ Total Responden } \\
\hline & & Jumlah $(n=100)$ & Persentase (\%) \\
\hline \multirow[t]{3}{*}{1} & Lama Menderita & & \\
\hline & a. $<2$ Tahun & 2 & 2 \\
\hline & b. $\geq 2$ Tahun & 98 & 98 \\
\hline \multirow[t]{3}{*}{2} & Komplikasi & & \\
\hline & a. Ada & 8 & 8 \\
\hline & b. Tidak Ada & 92 & 92 \\
\hline \multirow[t]{4}{*}{3} & Indeks Masa Tubuh & & \\
\hline & a. Kurang & 1 & 1 \\
\hline & b. Normal & 48 & 48 \\
\hline & c. BB Berlebih & 51 & 51 \\
\hline \multirow[t]{3}{*}{4} & Riwayat Keluarga & & \\
\hline & a. Ada & 30 & 30 \\
\hline & b. Tidak & 70 & 70 \\
\hline
\end{tabular}

Berdasarkan hasil analisis komplikasi menyatakan bahwa sebagian besar pasien yang menderita penyakit DM tipe 2 yang datang ke 4 puskesmas Kota Pekanbaru memiliki riwayat komplikasi sebanyak $8 \%$ yang terdiri dari $2 \%$ yang menderita DM selama 10 tahun dengan komplikasi stroke dan retinopati, $5 \%$ yang menderita DM selama 3 tahun dengan komplikasi retinopati dan terdapat juga $1 \%$ yang menderita DM selama 1 tahun dengan komplikasi retinopati.

Komplikasi DM timbul karena kadar glukosa tidak terkendali dan tidak tertangani dengan baik sehingga menyebabkan timbulnya komplikasi. Pada pasien yang telah menderita $>5$ tahun, berbagai mekanisme tubuh akan menyesuaikan diri untuk tetap memenuhi kebutuhan glukosa terutama di hati, otot, dan otak. Hal ini menyebabkan hilangnya kemampuan untuk mensintesis protein sebagai target untuk berikatan dengan reseptor. Sehingga hilangnya jaringan dan kelainan fungsi sel yang terjadi dapat memicu komplikasi (PB Perkeni, 2011).

Berdasarkan hasil analisis Indeks Massa Tubuh (IMT) menunjukkan bahwa pasien yang menderita penyakit DM tipe 2 yang datang ke 4 puskesmas Kota Pekanbaru dengan ketegori IMT berat badan berlebih sebanyak $51 \%$. IMT secara bersama-sama dengan variabel lainnya mempunyai hubungan yang signifikan dengan diabetes melitus. Penelitian menurut Sunjaya (2009) menemukan bahwa adanya pengaruh IMT terhadap diabetes melitus ini disebabkan oleh kurangnya aktivitas fisik serta tingginya konsumsi karbohidrat, protein, dan lemak yang merupakan faktor resiko dari obesitas (Teixeira et al. 2011).

Sedangkan berdasarkan hasil analisis riwayat keluarga menunjukkan bahwa pasien yang tidak memiliki 
riwayat keluarga diabetes melitus sebanyak $70 \%$. Sebagian besar responden yang tidak memiliki riwayat diabetes melitus disebabkan karena kurangnya pengaturan gaya hidup dan pola makan pasien selama sehat sehingga dapat meningkatkan kadar glukosa pasien. Dalam penelitian ini diketahui bahwa pasien yang tidak mempunyai riwayat keluarga dengan aktifitas fisik rendah sebanyak $49 \%$.

Menurut Kaban et al. (2007) menyatakan bahwa faktor yang menyebabkan terjadinya kasus DM dipengaruhi oleh gaya hidup berupa pola makan dan aktifitas fisik. Perubahan gaya hidup berupa pola makan yang berlebihan menyebabkan gangguan metabolisme zat-zat makanan baik berupa karbohidrat, protein, dan lemak yang menyebabkan penyakit diabetes melitus (Fibriana, 2005). Sedangkan kurangnya aktifitas fisik menyebabkan cadangan glikogen ataupun lemak akan tetap tersimpan di dalam tubuh, hal inilah yang memicu terjadinya DM tipe 2 (Yunir dan Soebardi, 2008).

Analisis Berdasarkan Data Pola Hidup Pasien

Berdasarkan hasil penelitian pada Tabel 2, menunjukkan bahwa sebagian besar pasien yang menderita penyakit DM tipe 2 memiliki aktivitas fisik yang rendah sebanyak $71 \%$ dan aktifitas fisik yang tinggi sebanyak $29 \%$. Berdasarkan hasil tersebut diketahui bahwa masih banyak pasien DM yang menjalani pola hidup yang tidak sehat. Hal ini ditandai dengan banyaknya pasien DM yang memiliki aktivitas fisik yang rendah. Banyak faktor yang mempengaruhi seseorang dapat menerapkan pola hidup sehat di antaranya pengetahuan, sikap, kepercayaan, adanya orang lain yang dijadikan referensi, dan sumber-sumber atau fasilitas-fasilitas yang dapat mendukung perilaku. Rendahnya pengetahuan mempengaruhi pola hidup termasuk aktifitas fisik seseorang.

Tabel 2. Hasil analisis data pola hidup pasien

\begin{tabular}{clcc}
\hline \multirow{2}{*}{ No } & \multirow{2}{*}{ Data Gaya Hidup } & \multicolumn{2}{c}{ Total Responden } \\
\cline { 2 - 4 } & Aktifitas Fisik & Jumlah $(\mathbf{n}=\mathbf{1 0 0})$ & Persentase (\%) \\
a. Tinggi & 29 & 29 \\
& b. Rendah & 71 & 71 \\
\hline 2 & Kebiasaan Merokok & 19 & 19 \\
& a. Ya & 81 & 81 \\
& b. Tidak & & \\
\hline
\end{tabular}

Rendahnya pengetahuan tersebut terjadi akibat minimnya informasi, masih rendahnya motivasi, serta lamanya jarak waktu antara pemberian informasi tentang DM dengan lamanya menderita DM yang 
menyebabkan hilangnya memori tentang informasi yang diberikan sehingga tidak mempengaruhi sikap seseorang terhadap pola hidup termasuk aktifitas fisiknya (Insiyah dan Hastuti, 2016).

Sedangkan berdasarkan hasil analisis mengenai riwayat merokok menunjukkan bahwa sebagian besar pasien yang menderita penyakit DM tipe 2 memiliki kebiasaan merokok sebanyak $19 \%$ dan tidak merokok sebanyak $81 \%$. Banyaknya pasien yang tidak merokok dikarenakan dalam 100 pasien yang diteliti lebih banyak pasien perempuan dibandingkan dengan laki-laki.
Perempuan mempunyai kebiasaan merokok yang sangat rendah atau bahkan tidak merokok dibandingkan dengan laki-laki (Irawan, 2010). Sebaliknya, masih terdapatnya 19\% pasien DM yang masih merokok dapat disebabkan kurangnya informasi yang diperoleh (Sarwono, 2004). Namun, berdasarkan hasil penelitian yang dilakukan oleh Sirait et al. (2002) menunjukkan bahwa di samping pengetahuan yang kurang, pengaruh adiksi dari nikotin yang terdapat pada rokok juga mempengaruhi kebiasaan merokok seseorang.

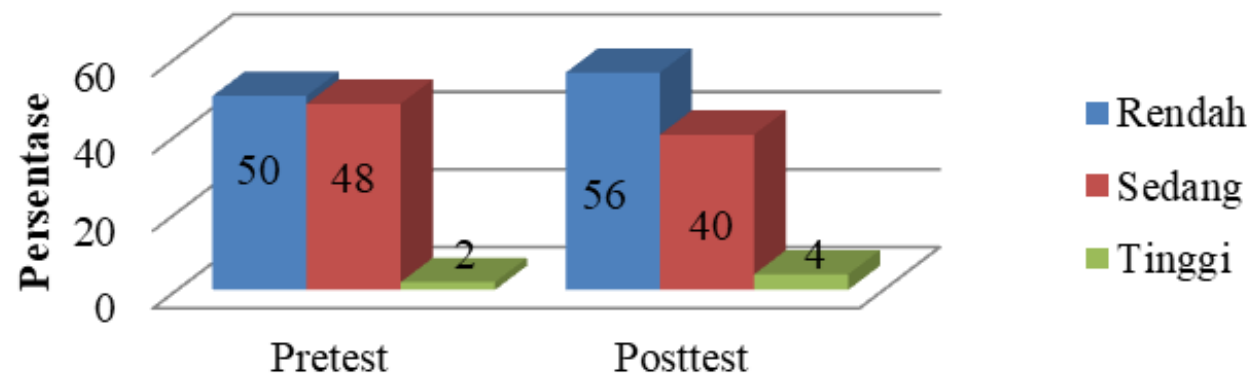

Gambar 4. Grafik hasil analisis tingkat ketaatan pretest dan posttest pasien kelompok kontrol.

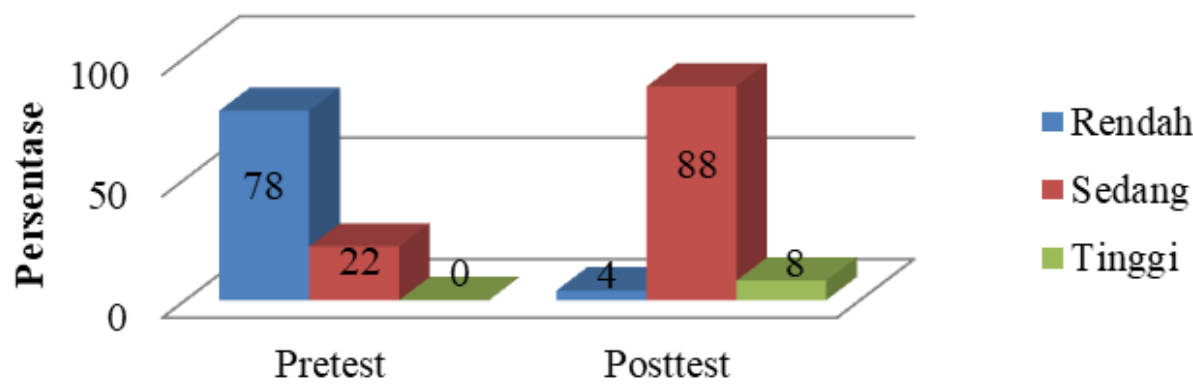

Gambar 5. Grafik hasil analisis tingkat ketaatan pretest dan postest pasien kelompok perlakuan. 
Analisis Berdasarkan Tingkat Ketaatan Pretest dan Posttest Pasien

Berdasarkan hasil analisis tingkat ketaatan yang dilakukan pada kelompok kontrol (Gambar 4) dan kelompok perlakuan (Gambar 5), diperoleh hasil analisis kategori ketaatan pasien pada pretest untuk kelompok kontrol didapatkan tingkat ketaatan tinggi yaitu sebanyak $2 \%$, tingkat ketaatan sedang sebanyak 48\%, dan tingkat ketaatan rendah sebanyak $50 \%$. Pada saat posttest, tingkat ketaatan tinggi sebanyak $4 \%$, untuk kategori ketaatan sedang sebanyak 40\%, dan untuk ketaatan rendah sebanyak 56\%. Dari data tersebut terlihat peningkatan ketaatan pretest dan posttest pada tingkat ketaatan rendah dari $50 \%$ menjadi $56 \%$ dan untuk tingkat ketaatan tinggi dari $1 \%$ menjadi $2 \%$. Namun peningkatan tersebut tidak terlalu tinggi. Sedangkan untuk tingkat ketaatan sedang mengalami penurunan dari $48 \%$ menjadi $40 \%$. Penurunan tingkat ketaatan pada kelompok kontol ini dikarenakan pasien tidak diberikan suatu perlakuan sehingga tidak mempengaruhi tingkat ketaatannya. Rendahnya ketaatan pasien juga dapat terjadi karena adanya hambatan-hambatan yang dialami pasien DM. Hambatan ketaatan menyebabkan ketidaktaatan yang teridentifikasi meliputi faktor pasien dan kepercayaan pasien, sifat komunikasi antara pasien dan profesional kesehatan, dan berbagai faktor perilaku pasien lainnya.

Selain itu, banyaknya pasien yang lupa dalam minum obat tersebut kemungkinan dapat disebabkan oleh faktor usia. Berdasarkan hasil penelitian diketahui bahwa dari 34 pasien yang lupa dalam minum obat tersebut sebanyak 26 pasien yang berumur $>50$ tahun. Faktor umur merupakan salah satu hambatan ketaatan. Bertambahnya umur maka terjadi penurunan kemampuan kognitif yang menyebabkan pasien menjadi tidak taat dalam minum obat. Notoatmodjo (2003) menyatakan bahwa usia memiliki hubungan dengan tingkat keterpaparan, besarnya resiko penyakit, serta resistensi terhadap penyakit. Orang yang sudah tua akan menjadi lebih terisolasi saat mereka semakin tua, serta terdapat penurunan fungsi sosial seperti intelektual, memori, dan kemampuan memecahkan masalah (Niven, 2002).

Hasil analisis data menunjukkan responden yang memiliki tingkat kepatuhan rendah adalah respoden yang berusia lebih dari atau sama dengan 45 tahun. Menurut Erawatyningsih et al. (2009) menyatakan bahwa usia lebih dari 45 tahun, lebih tidak teratur menjalankan pengobatan karena kurangnya motivasi yang kuat untuk sehat dan memperhatikan kesehatannya. Sedangkan usia kurang dari 45 tahun lebih cenderung memiliki motivasi yang kuat untuk sehat. Selain faktor usia, riwayat komplikasi juga dapat menurunkan tingkat ketaatan seseorang karena regimen pengobatan yang kompleks.

Sedangkan hasil analisis untuk kelompok perlakuan menunjukkan bahwa terdapat peningkatan ketaatan 
pasien yang cukup tinggi dari tingkat ketaatan sedang yang hanya $22 \%$ menjadi $88 \%$ dan juga dijumpai pasien dengan tingkat ketaatan tinggi meningkat menjadi 8\%. Menurut Rantucci (2009) ada 4 aspek penting dalam pencegahan ketidaktaatan, salah satunya adalah dengan memberikan alat pengingat dan pengatur pemakaian obat. Peningkatan ketaatan yang cukup besar pada kelompok perlakuan ini dikarenakan penggunaan wadah pengingat pil dan kemasan sekali pakai yang digunakan dalam penelitian untuk meningkatkan ketaatan responden penelitian.

Peningkatan ketaatan pada kelompok perlakuan ini karena pengaruh dari pemberian wadah pengingat pil dan kemasan sekali pakai yang diberikan pada saat pretest. Berdasarkan hasil wawancara yang dilakukan pada saat posttest menyatakan bahwa peningkatan ketaatan pasien karena pemberian wadah tersebut membantu pasien dalam minum obat karena sudah tersusun dalam dosis sekali pakai dan dosis sehari pakai. Selain itu, memudahkan dalam membawa obat ketika ingin berpergian karena pasien tidak perlu membawa plastik obat lagi dalam jumlah banyak dan mudah dimasukkan ke saku karena ukuran wadah kecil.

Analisis Bivariat Berdasarkan Perubahan Skor Ketaatan Pasien DM Tipe 2

Berdasarkan hasil analisis dari uji wilcoxon untuk kelompok kontrol didapatkan nilai $p=0,928 \quad(p>0,05)$, dengan demikian tidak terdapat pengaruh signifikan antara ketaatan pretest dan posttest untuk kelompok kontrol. Sedangkan untuk kelompok perlakuan didapatkan nilai $\mathrm{p}=0,000$ $(p<0,05)$, dengan demikian terdapat pengaruh yang signifikan antara ketaatan pretest dan posttest untuk kelompok perlakuan. Hasil dari penelitian ini didapatkan bahwa terdapat pengaruh yang signifikan dari pemberian wadah pengingat pil dan kemasan sekali pakai terhadap tingkat ketaatan dari pretest dan posttest pada kelompok perlakuan. Berbeda halnya pada kelompok kontrol yang didapatkan bahwa tidak terdapat pengaruh yang signifikan dari perubahan tingkat ketaatan pretest dan posttest.

Hasil analisis pengaruh perubahan tingkat ketaatan pada saat pretest dan posttest kelompok kontrol dan kelompok perlakuan dengan menggunakan uji wilcoxon signed ranks test dipaparkan berikut ini. Dari hasil uji wilcoxon signed ranks test, kelompok kontrol (tanpa pemberian wadah pengingat pil dan kemasan sekali pakai), membandingkan antara ketaatan pretest kontrol dan posttest kontrol didapatkan hasil sebagai berikut: 11 pasien mengalami negatif ranks, 13 pasien mengalami positif ranks, dan 26 pasien mengalami mengalami konstan. Dari hasil ketaatan pretest dan posttest kontrol didapat $p$ value 0,928 , artinya terdapat perbedaan yang tidak signifikan karena $\mathrm{p}$ value $>0,05$.

Menurut Rantucci (2009) ada 5 masalah mengenai ketidaktaatan pasien dalam mengkonsumsi obat, yaitu 
menggunakan atau mendapatkan obat yang benar tetapi terlalu sedikit, menggunakan atau mendapatkan obat yang benar tetapi terlalu banyak, frekuensi penggunaan obat yang tidak sesuai, tidak menggunakan atau mendapatkan obat yang diresepkan, dan cara minum obat yang tidak benar. Dari hasil uji wilcoxon signed ranks test kelompok perlakuan (dengan pemberian wadah pengingat pil dan kemasan sekali pakai), yang membandingkan antara ketaatan posttest perlakuan dan pretest perlakuan didapat hasil sebagai berikut: 1 pasien mengalami negatif ranks, 44 pasien mengalami positif ranks, dan 5 pasien mengalami konstan. Dari hasil ketaatan posttest dan pretest perlakuan didapat $p$ value 0,000 , artinya terdapat pengaruh yang signifikan karena $\mathrm{p}$ value $<0,05$. Hal ini karena pada wadah pengingat pil dan kemasan sekali pakai yang diberikan kepada kelompok perlakuan dapat memudahkan pasien dalam minum obat, lebih menarik, mudah dibawa kemana-mana dan pentingnya ketaatan dalam terapi DM. Ini menunjukkan bahwa wadah pengingat pil dan kemasan sekali pakai yang diberikan, efektif sebagai salah satu alat untuk mengurangi angka ketidaktaatan pasien DM.

Tabel 3. Hasil analisis bivariat perubahan skor ketaatan pasien sebelum dan sesudah pemberian alat wadah pengingat pil dan kemasan sekali pakai dengan uji wilcoxon

\begin{tabular}{lccc}
\hline & $\mathbf{n}$ & $\begin{array}{c}\text { Median } \\
\text { (Minimum-Maksimum) }\end{array}$ & $\mathbf{p}$ \\
\hline Kontrol & & & \\
$\quad$ Pretest & 50 & $5,50(4-8)$ & 0,928 \\
$\quad$ Posttest & 50 & $5,00(4-8)$ & \\
$\begin{array}{c}\text { Perlakuan } \\
\text { Pretest }\end{array}$ & 50 & $5,00(3-7)$ & 0,000 \\
Posttest & 50 & $7,00(4-8)$ & \\
\hline
\end{tabular}

Sedangkan berdasarkan hasil uji Mann-whitney yang dilakukan, didapatkan hasil $p$ value yaitu $p=0,000$ $(\alpha<0,05)$ sehingga dapat disimpulkan bahwa terdapat perbedaan yang signifikan antara kelompok perlakuan terhadap kelompok kontrol. Hal ini berarti pemberian Medication Aids berupa wadah pengingat pil dan kemasan sekali pakai dapat berpengaruh signifikan terhadap perubahan tingkat ketaatan pada kelompok perlakuan yang diberikan.

Terdapat banyak intervensi untuk meningkatkan ketaatan pengobatan dan telah dijelaskan untuk kondisi klinis yang berbeda. Intervensi yang dilakukan dapat berupa intervensi perilaku, intervensi pendidikan, intervensi perawatan terpadu, intervensi 
komunikasi resiko dan intervensi alat pengingat ketaatan.

Tabel 4. Hasil perbedaan skor ketaatan kelompok kontrol dan perlakuan dengan uji Mann-Whitney

\begin{tabular}{cccc}
\hline & $\mathbf{n}$ & $\begin{array}{c}\text { Median } \\
\text { (Minimum-Maksimum) }\end{array}$ & p \\
\hline Kontrol & 50 & $0,00(-2-2)$ & 0 \\
\hline Perlakuan & 50 & $2,00(-1-3)$ & 000 \\
\hline
\end{tabular}

\section{Simpulan}

Dari hasil penelitian diketahui terdapat pengaruh pemberian wadah pengingat pil dan kemasan sekali pakai terhadap ketaatan pasien DM tipe 2 di beberapa Puskesmas Kota Pekanbaru dengan nilai $p=0,000(p<0,05)$.

\section{Daftar Pustaka}

Abrahim, M. 2011. Self-care in type 2 diabetes: a systematic literature review on factors contributing to self-care among type 2 diabetes mellitus patients. Tesis. Linnaeus University.

Alfian, S.D., Sukandar, H., Lestari, K., Abdullah, R. 2016. Medication adherence contribute to an improved quality of life in type 2 diabetes mellitus patients: a cross-sectional study. Diabetes Therapy, 7(4):755-764.

American Diabetes Association, 2003. Treatment of hypertension in adults with diabetes. Diabetes Care, 26(suppl 1):s80-s82.

WHO. 2003. Adherene Long-Term Therapies.

http://www.who.int/mip/2003/ other_document/en/E\%20AA\%2
OAdherence.pdf. Data diakses pada 27 Februari 2010.

Depkes RI. 2005. Pharmaceutical Care untuk Penyakit Diabetes Mellitus. Jakarta: Direktorat Bina Farmasi Komunitas dan Klinik Departemen Kesehatan Republik Indonesia.

WHO. 2008. World Health OrganizationDiabetes Facts, http://www.who.int. Data diakses pada 2 Agustus 2016.

BPS. 2010. Data Hasil Sensus Penduduk 2010 di Provinsi Riau. Riau: Badan Pusat Statistik.

PB Perkeni. 2011. Konsensus Pengelolaan dan Pencegahan Diabetes Mellitus Tipe 2 di Indonesia. Jakarta: PB Perkeni.

Dinkes Kota Pekanbaru. 2013. Data Penyakit Diabetes Mellitus. Pekanbaru: Dinas Kesehatan Kota Pekanbaru.

Ayu, N.P.M. dan Damayanti, S. 2015. Pengaruh pendidikan kesehatan terhadap tingkat pengetahuan pasien diabetes melitus tipe 2 dalam pencegahan ulkus kaki diabetik di Poliklinik RSUD 
Panembahan Senopati Bantul. Jurnal Keperawatan Respati, 2(1):1-9.

Bernal, H., Wolley, S., Schensul, J.J., Dickinson, J.K. 2000. Correlates of self efficacy in diabetes selfcare among hispanic adults with diabetes. The Diabetes Educator, 26(4):673-680.

Erawatyningsih, E., Purwanta, Subekti, H. 2009. Faktor-Faktor yang mempengaruhi ketidakpatuhan berobat pada penderita tuberkulosis paru. Berita Kedokteran Masyarakat, 25(3):117-124.

Fibriana, D. 2005. Hubungan pola makan dengan kadar gula darah pada penderita diabetes mellitus di klinik pratama analisa pekalongan. Skripsi. Fakultas Kedokteran, Universitas Diponegoro.

Irawan, D. 2010. Prevalensi dan faktor risiko kejadian diabetes melitus tipe 2 di daerah urban Indonesia. Tesis. Universitas Indonesia.

Insiyah dan Hastuti, R.T. 2016. Tingkat pengetahuan dan kepatuhan tentang diit diabetes melitus pada pasien diabetes melitus di Puskesmas Sibela Kota Surakarta. Jurnal Terpadu IImu Kesehatan, 5(1):14-21.

Iswanto. 2004. Beberapa faktor yang berhubungan dengan kadar gula darah puasa pasien rawat jalan diabetes melitus tipe 2 Puskesmas Pasar Minggu. Skripsi. Fakultas Kesehatan
Masyarakat, Universitas Indonesia.

Kaban, S.M.S., Irnawati, Sari, W.A. 2007. Pengembangan model kejadian diabetes mellitus tipe 2 di Kota Sibolga Tahun 2005. Majalah Kedokteran Nusantara, 40(2):119-128.

Misnadiarly. 2006. Diabetes Mellitus: Gangren, Ulcer, Infeksi Menanggulangi dan Mencegah Komplikasi. Edisi I. Jakarta: Pustaka Populer.

Mrcos, G. 2005. Efektivitas Pendidikan Terstruktur pada Penderita DM Tipe 2. Santa Coloma: Catalan Institute of Health Santa Coloma.

Napirah, M.Y., Rahman, A., Tony, A. 2016. Faktor-faktor yang berhubungan dengan pemanfaatan pelayanan kesehatan di wilayah kerja Puskesmas Tambarana Kecamatan Poso Pesisir Utara Kabupaten Poso. Jurnal Pengembangan Kota, 4(1):29-39.

Niven, N. 2002. Psikologi Kesehatan Pengantar untuk Perawat dan Profesional Kesehatan Lain. Jakarta: Buku Kedokteraan EGC.

Notoatmodjo, S. 2003. Pendidikan dan Perilaku Kesehatan. Jakarta: Rineka Cipta.

Osterberg, L. dan Blaschke, T. 2005. Adherence to medication. The New England Journal of Medicine, 353(5):487-491. 
Rantucci, M.J. 2009. Komunikasi Apoteker Pasien. Edisi 2. Jakarta: Kedokteran EGC.

Sarwono. 2004. Sosialisasi Kesehatan. Yogyakarta: Gadjah Mada University Press.

Sirait, A.M., Pradono, Y., Toruan, I.L. 2002. Perilaku merokok di Indonesia. Buletin Penelitian Kesehatan, 30(3):139-152.

Sunjaya, I.N. 2009. Pola konsumsi makanan tradisional bali sebagai faktor resiko diabetes melitus tipe II di Tabanan. Jurnal Skala Husada, 6(1):75-81.

Teixeira, L.E., Nunes, S., Teixeira, F., Reis, F. 2011. Regular physical exercise training assists in preventing type 2 diabetes development focus on its antioxidant and anti inflammatory properties. Cardiovascular Diabetology, 28(3):1-15

Therney, Lawrence, Stephen, J. dan Papedakis. 2002. Diagnosis dan Terapi Kedokteran IImu Penyakit
Dalam. Jakarta: Penerbit Abdul Gafur.

Trisnawati, S.K. dan Setyorogo, S. 2013. Faktor risiko kejadian diabetes melitus tipe 2 di Puskesmas Kecamatan Cengkareng Jawa Barat. Jurnal IImiah Kesehatan, 5(1):6-11.

Winasthi, M.Y.D. 2010. Pengaruh pemberian alat bantu ketaatan dan informasi saat home visit pada perilaku pasien ISPA Puskesmas Kalibawang. Skripsi. Ilmu Farmasi, Universitas Sanata Dharma.

Wijaya, N., Faturrohmah, A., Agustin, W.W., Soesanto, T.G., Kartika, D. Prasasti, H. 2015. Profil kepatuhan pasien diabetes melitus Puskesmas Wilayah Surabaya Timur dalam menggunakan obat dengan metode pill count. Jurnal Farmasi Komunitas, 2(1):18-22.

Yunir, E. dan Soebardi, S. 2008. Terapi Non Farmakologis pada Diabetes Melitus. Jakarta: Departemen IImu Penyakit Dalam FKUI. 